\title{
Larval longevity and competency patterns of Caribbean reef- building corals
}

\author{
Margaret W. Miller ${ }^{\text {Corresp., }, 2}$, Allan J. Bright ${ }^{1,3}$, Rachel E. Pausch ${ }^{1,3,4}$, Dana E. Williams ${ }^{1,3}$ \\ 1 NOAA-National Marine Fisheries Service, Southeast Fisheries Science Center, Miami, Florida, United States \\ 2 SECORE International, Miami, Florida, United States \\ 3 Cooperative Institute of Marine and Atmospheric Studies, University of Miami, Miami, Florida, United States \\ 4 Dept of Ecology and Evolutionary Biology, University of California, Santa Cruz, Santa Cruz, California, United States \\ Corresponding Author: Margaret W. Miller \\ Email address: m.miller@secore.org
}

The potential for long-distance larval dispersal depends on the longevity of planktonic, free-swimming larvae and their capacity to successfully recruit to reef habitat. We present multi-year laboratory observations of the persistence of planular larvae and settlement competency over time for cohorts derived from the same parental populations of the most important Caribbean reef building coral species, Orbicella faveolata and Acropora spp. Despite variability among years/cohorts, larvae of both species display capacity for extended longevity (up to $83 \mathrm{~d}$ ) and competency (demonstrated at up to $48 \mathrm{~d}$ ). Both species also displayed significantly reduced survivorship and lower realized settlement under elevated temperatures. Although the observed levels of settlement in $24 \mathrm{~h}$ competency assays was extremely variable, the timing of onset of competence was highly consistent among years/cohorts but distinct between species. Orbicella faveolata displayed onset of competence during day 3-5 or 4-7 (with or without exposure to positive settlement cue) after spawning; whereas, onset for Acropora spp. was day 7-8 or day 10-11 (with or without cue, respectively). This longer pre-competency period for Acropora spp. nonetheless corresponded to a greater persistence of $A$. palmata larvae to this age of competence $(71-83 \%$ of initial cohort compared to $54-55 \%$ for 0 . faveolata). Such life history variation implies meaningful differences in likely dispersal potential between these imperiled reef-building species. 
Corresponding Author:

17 Margaret W. Miller ${ }^{1,2}$

18 Email address:

m.miller@secore.org 
23 ABSTRACT:

24 The potential for long-distance larval dispersal depends on the longevity of planktonic, free-

25 swimming larvae and their capacity to successfully recruit to reef habitat. We present multi-year

26 laboratory observations of the persistence of planular larvae and settlement competency over

27 time for cohorts derived from the same parental populations of the most important Caribbean

28 reef building coral species, Orbicella faveolata and Acropora spp. Despite variability among

29 years/cohorts, larvae of both species display capacity for extended longevity (up to $83 \mathrm{~d}$ ) and

30 competency (demonstrated at up to $48 \mathrm{~d}$ ). Both species also displayed significantly reduced

31 survivorship and lower realized settlement under elevated temperatures. Although the observed

32 levels of settlement in $24 \mathrm{~h}$ competency assays was extremely variable, the timing of onset of

33 competence was highly consistent among years/cohorts but distinct between species. Orbicella

34 faveolata displayed onset of competence during day 3-5 or 4-7 (with or without exposure to

35 positive settlement cue) after spawning; whereas, onset for Acropora spp. was day 7-8 or day 10-

3611 (with or without cue, respectively). This longer pre-competency period for Acropora spp.

37 nonetheless corresponded to a greater persistence of $A$. palmata larvae to this age of competence

38 (71-83\% of initial cohort compared to $54-55 \%$ for $O$. faveolata). Such life history variation implies meaningful differences in likely dispersal potential between these imperiled reef-building 40 species. 
42 Introduction:

43 Connectivity of broadcast spawning, reef-building coral populations depends upon the

44 dispersal of minute pelagic larvae. Due to their inapparency in nature and challenge to culture,

45 these dispersive life history phases remain poorly characterized, especially for Caribbean

46 species. Meanwhile, the imperiled status of Caribbean reef-building coral species (especially

47 Acropora spp. and Orbicella spp.) highlights the importance of connectivity in allowing for

48 long-distance recruitment to replenish locally depauperate stands. Improved understanding of

49 early life history stages can yield improved prediction of connectivity and recovery potential for

50 specific reef populations.

51 For example, larval longevity and settlement competence are important determinants of

52 dispersal potential directly affecting population connectivity and recovery potential. While an

53 increasing number of studies on coral larvae have been documented, numerous questions remain

54 regarding factors and mechanisms involved with larval longevity and settlement (Gleason and

55 Hofmann 2011). Currently, several published studies have documented these important life

56 history characteristics via empirical laboratory observations for Pacific spawning corals

57 (Connolly and Baird 2010; Moneghetti et al. 2019; Nozawa and Harrison 2008; Tay et al. 2011).

58 However, such studies are extremely rare for Caribbean corals (Davies et al. 2017 being the

59 notable exception).

60

61 dramaticallyLarval longevity for five Indo-Pacific species (Acropora latistella, Montastraea magnistellata, Pectinia paeonia, Favia pallida, and Goniastrea aspera) has been documented up

63 to several hundred days (Graham et al. 2008), while other observations show a much shorter

64 larval duration of approximately 30-40 days for two other Pacific Acropora spp. (A. muricata

65 and A.valida; Nozawa and Harrison 2008). Settlement competency periods are generally shorter 
66 than maximum larval longevity with peaks occurring approximately 3-10 days post fertilization

67 (Nozawa and Harrison 2008, Connolly and Baird 2010, Tay et al. 2011). However, Orbicella

68 franksi demonstrated an exception with a peak range of settlement response at 75-120 days post

69 fertilization (Davies et al. 2017). These studies highlight the interspecific variability in

70 phenotypic life history traits that may lead to underestimates in connectivity modelling

71 projections. Parameter estimates typically used in published dispersal models are for a larval

72 duration of 10-40 days (Baums et al. 2006; Holstein et al. 2014; Indrayanti et al. 2019; Schill et

73 al. 2015) and a competency period of 30 days or less (Drury et al. 2018; Holstein et al. 2014;

74 Indrayanti et al. 2019; Kool et al. 2011). While variation among individuals and cohorts may

75 also be important both in modelling and in the growing implementation of larval rearing for coral

76 restoration (Randall et al. 2020), most empirical studies characterize only a single cohort of

77 larvae.

In this study, we focus on the primary Caribbean reef-building corals, Orbicella faveolata and Acropora palmata, both of which, to our knowledge, lack published documentation of longevity or competency periods. We conducted two types of laboratory observations to

81 document 1) larval longevity (i.e., persistence of swimming larvae over time ) as affected by

82 temperature and in the absence of positive settlement cues, and 2) larval competency dynamics

83 over time, when presented with a positive settlement cue. Additionally, these assays were

84 performed over multiple years with each species to document variation in these parameters

85 among years or cohorts.

87 Methods: 
88

89

90

91

92

93

94

95

96

97

98

Two separate lab studies are reported here, and referred to as the 'larval longevity' experiments (incorporating a temperature treatment) and the 'competency assays.' Competency assays were conducted with individual cohorts of larvae of available species during the spawning season each year from 2012 to 2017 . The longevity studies were conducted the latter three years (2015 to 2017). Acropora palmata and Orbicella faveolata were the primary target species, and were attempted for both types of experiments in all years; however, each species was not always available due to inconsistencies in spawning, fertilization, and larval condition. Acropora cervicornis was targeted only in 2017 . The general procedure for these two experiment types is described here with specific details and deviations for each year given in Table 1.

Generally, gamete bundles were collected from reefs near Key Largo, Florida, USA on predicted spawning nights for each species using tent-shaped, collectors constructed of fine insect screen (so-called 'noseeum netting') with an inverted jar at the top for bundle collection. Bundles were returned to the boat and combined immediately for cross-fertilization. After returning to a field lab (approximately $1.5 \mathrm{~h}$ fertilization duration), excess sperm were rinsed away and embryos were left in filtered seawater overnight with very low aeration.

For the longevity studies, replicate aliquots of embryos (100 or 120 for Acropora spp; 200 for $O$. faveolata) were counted out either on day 1 or day 2 after spawn (dAS) and placed in glass bowls with approximately $400 \mathrm{ml}$ filtered seawater (either 1um or $5 \mathrm{um}$ filtration) collected from offshore reef environments. These dishes were then divided between two outdoor, recirculating water baths providing two temperature treatments $(n=5)$. These temperature treatments were somewhat different in both mean and variability between years (Table 1), but the 'cool' treatment was targeted in the range of $29.0-30.0^{\circ} \mathrm{C}$ while the 'high' treatment was in the range of $30.5-31.5^{\circ} \mathrm{C}$ during different years. The ambient surface temperature over upper 
111 Florida Keys reefs in August is approximately $30^{\circ} \mathrm{C}$ in modern times, approximately $1{ }^{\circ} \mathrm{C}$ higher

112 than the turn of the $20^{\text {th }}$ century (Kuffner et al. 2015).

Water changes (approximately 75\% volume) in each dish were conducted every other day

114 with filtered reef water. Full water changes were conducted during counts of the larvae

115 remaining in each dish, conducted every other day for the first two weeks and then less

116 frequently (approximately weekly) thereafter. These counts scored organisms as

117 pelagic/swimming larvae, settled polyps, or MUPs (metamorphosed, unattached polyps). Larvae

118 that metamorphosed in the water column (MUPs) were never observed to attach so their viability

119 as recruits is unclear, but we chose to exclude them from both estimates of larval supply and

120 mortality. Settled polyps remained in the bowls in 2015, but during 2016 and 2017, all settlers

121 were removed during each count. Data are reported as larval supply (remaining swimming

122 planulae larvae) over time (i.e. age) and mortality over time (initial \# minus remaining

123 swimming planulae minus cumulative \# settlers minus cumulative \# MUPs).

There was a discontinuity during the 2015 and 2016 experiments at the completion of our

field expedition (approximately 1 month following spawning). The individual dishes were

lidded and transported in a dry cooler from the field lab in Key Largo back to the Southeast

127 Fisheries Science Center in Miami FL. In 2015, the recirculating temperature-controlled baths

were re-assembled, and the temperature treatments were maintained until all larvae expired or

settled. In 2016, the warm treatment was terminated when this move was made, and only a at 23-25 dAS due to forced evacuation before Hurricane Irma. was analyzed using the "survival" (Therneau 2020) and "survminer" (Kassambara et al. 2019) 
134 packages in $\mathrm{R}$, with replicate dish as a random factor. Kaplan-Meier survival curves were

135 estimated for each treatment within a cohort and compared using a log rank test.

$136 \quad$ For the competency assays, larger batch cultures of larvae were maintained in round

137 culture chambers that had a $100-\mu \mathrm{m}$ mesh bottom and a continuous, recirculating slow drip

138 around its walls. Culture chambers were housed in outdoor recirculating seawater systems

139 containing reef-collected seawater with temperature control, salinity maintained at 35-37 ppt by

140 addition of distilled water to compensate for evaporation, a UV sterilizer, and $5 \mu \mathrm{m}$ filtration.

141 Partial exchange with new reef water was conducted periodically to maintain water quality. No

142 effort was made to deprive these larvae of settlement cues since raw reef water was exchanged

143 periodically and other tanks in the recirculating seawater system contained natural reef rubble.

144 Beginning two to three days after spawn, replicate aliquots of larvae were counted out (10 for

145 Acropora spp;; 20 for O. faveolata) into individual wells in two 6-well polystyrene culture plates

146 along with a fragment of substrate with crustose coralline algae to provide positive settlement

147 cues (n=12; Fig 1A). In most years, this substrate was a fragment chipped from a freshly

148 collected piece of reef rubble, though in 2014 chips of artificial ceramic substrate that had been

149 conditioned in local reef habitat for over two months were used. Rubble or ceramic chips were

150 approximately $1 \times 1 \mathrm{~cm}$ in size. Starting in 2015, glass inserts were placed inside the polystyrene

151 6-well plates such that settlement took place in the absence of plastic.

152 Generally, competency assays were established in late afternoon and scored

153 approximately $24 \mathrm{hr}$ later. Settlement of larvae (i.e., firmly attached and beginning to flatten;

154 settlement, sensu Miller and Mundy (2003; Fig 1B) was scored under a fluorescent dissecting

155 microscope. After each scored assay, larvae were discarded and a fresh selection of larvae and

156 fresh rubble chips were used for each subsequent assay. These assays were initially conducted 
157 daily, with reduced frequency to every other day after about 2 weeks and were continued as long

158 as healthy-looking larvae (i.e., elongated and swimming) were available from the initial batch

159 culture with the following exceptions. In the first year of the study (2012), the competency

160 assays were not initiated until day 14 and were conducted less frequently. An additional

161 competency assay for Acropora spp was performed at a later date (after the initial batch culture

162 was expended) using remaining larvae from the longevity assays in 2016 (the discontinued

163 'warm' treatment larvae when the experiment was moved back from the field lab) and in 2017

164 (all larvae from the longevity assays prior to required hurricane evacuation). Lastly, in 2013,

165 two separate cohorts (termed $\mathrm{a}$ and $\mathrm{b}$ ) collected on sequential nights from different sites were

166 tested separately.

167

All collections were permitted by the Florida Keys National Marine Sanctuary (Permits \# FKNMS-2012-101, FKNMS-2014-047, and FKNMS-2016-047-A1).

169

170

171

172

173

174

175

176

177

178

Results:

Both experiments were conducted under generally consistent procedures (exceptions noted in Table 1) with larvae derived from the same general parent population (i.e., collected from 2-3 sites within $\sim 12 \mathrm{~km}$ distance), yet overall settlement rates and competency patterns over time were extremely variable. In contrast, onset of competency was quite consistent among experimental trials and cohorts within a species, while being distinct between species.

The pattern of larval supply (i.e., remaining swimming planula) over time for each trial is shown in Fig. 2. The maximum larval longevity (i.e., the persistence of swimming planula larvae) we observed was 83 days for O. faveolata (2015) and 70 days for A. palmata (2016). The first observation of metamorphosis in these experiments (no cue) was on either 10 or $11 \mathrm{dAS}$ for 
179 four separate trials with Acropora $\operatorname{spp}$ (A. palmata in 2015, 2016, and 2017 plus A. cervicornis in

180 2017) and for O. faveolata, day 7 in 2015 and day 4 in 2017 (Fig. 2). The patterns of larval

181 mortality are quite consistent with high mortality up to 4 or $5 \mathrm{dAS}$, after which mortality rate is

182 greatly moderated in O. faveolata, and largely flat in Acropora spp. (Suppl. Fig 1).

In five out of six trials, the warmer temperature treatments had mild but significant

effects on larval supply over time (exception: $2016 \mathrm{~A}$. palmata) and resulted in substantially

fewer observed settlers for both species in 2015 and 2016 when the mean treatment increment

was approximately $1^{\circ} \mathrm{C}$ (Table 1, Fig 2 A, B, E). This effect was much larger for both Acropora

more variable (Table 1, Fig. $2 \mathrm{C}, \mathrm{D}$ ), though the effect of this more extreme temperature

exposure on $O$. faveolata remained mild (Fig 2F). Specifically, at the time of first observed

metamorphosis (no cue), on average, $\sim 40 \%$ as many larvae remained in the warm treatment

relative to the cool for $A$. cervicornis (at $11 \mathrm{dAS}$ ), $\sim 71 \%$ as many $A$. palmata (at $11 \mathrm{dAS}$ ), and

$\sim 90 \%$ as many O. faveolata (at 4 dAS; Fig. 2 C, D, F; Table 2).

faveolata, with competency assay data available over 25-40 dAS, whereas for Acropora spp.

195

196

197

198

199

200

201 most of the batch cultures had expired in less than 15 days, often due to spontaneous

metamorphosis in the water column. There was remarkable variability between years in the overall settlement rates with the highest observed daily mean for $O$. faveolata ranging from $21 \%$ (2014) to over 50\% (2015) and for A. palmata the highest daily mean settlement rate ranging from below $10 \%$ to $80 \%$ (Fig. 3, 4).

The strongest pattern in all of the competency assays is the observation of higher variability among replicates within each trial run than among ages. Virtually all trials of these 
202 assays had individual replicates with zero settlement, simultaneous with other replicates with

203 high settlement (maximum levels of $80-100 \%$ in $24 \mathrm{~h}$; Fig. 3, 4), thus, obscuring any clear

204 patterns in competency with age such as hypothesized patterns of senescence. We also

205 calculated the time windows where highest settlement occurred for each trial (i.e., settlement

206 values within $25 \%$ of the maximum settlement observed for a cohort; Suppl. Fig. 2, 3). For $O$.

207 faveolata, highest settlement occurred during days 6-10 (2015 and 2017) or days 20-27 (2012-

208 2014). Acropora spp. settlement peaked at days 8-15 for the 2013, 2014, and 2017 cohorts

209 (Suppl. Fig. 2). However, in 2016 the maximum mean A. palmata settlement of 28\% was

210 observed at $35 \mathrm{dAS}$ (Fig 3C), the latest age for which a full competency assay was run for this

211 species. The latest competency was demonstrated at $48 \mathrm{dAS}$ for O. faveolata (2012; mean $20 \%$

212 settlement per 24 h, Fig 4A). Meanwhile, some cohorts/years did show marked declines in

213 competence with age consistent with senescence (e.g., O. faveolata in 2015; Fig 4E).

Although the initial observations of settlement in the competency assays was at day 3 or

4 for all species, the onset of substantial settlement response at the population level was

216 consistently earlier for $O$. faveolata, with mean settlement rate increasing during the range of 3-

2175 dAS whereas in Acropora spp, this increase of competency was not observed until day 6-8 (Fig $2183-4)$.

219 Discussion:

This study is among the first to empirically document pre-competency, competency, and studies have documented extended larval duration for Indo-Pacific broadcast spawning corals as well as timing and pattern of settlement. Connolly and Baird (2010) characterize both larval

224 survivorship and competence in five species, all of which showed a peak in settlement 
225 competence in the range of 4-13 days with an asymptotic decline thereafter. Although all five

226 species showed larvae remaining up to 90-120 dAS, after 30 days, four of the five species

227 showed a settlement response of less than 10\% (and rapidly declined) in 72-hour assays, and

228 settlement was not observed after 36 days in three of the species. All five species showed a post-

229 competence (senescent) period wherein surviving larvae failed to settle in standard assays. In

230 contrast, while our results show larval longevity of up to 60-70 dAS for Acropora palmata and

$23183 \mathrm{dAS}$ for Orbicella faveolata, there is no clear pattern of senescence. For example, several of

232 the highest mean settlement responses were observed at 35 dAS (e.g., 2016 for A. palmata; 2012

233 and 2013b for O. faveolata; Fig 3, 4). Davies et al. (2017) similarly showed no pattern of

234 senescence over more than $120 \mathrm{dAS}$ for Orbicella franksi. However, the overall longevity of the

235 batch cultures used for our competency assays, especially for A. palmata, was compromised as

236 most of these larvae metamorphosed spontaneously (MUPs) in these batch cultures within 2 to 3

237 weeks. Metamorphosis without attachment has been demonstrated to result from a specific

238 inducer derived from bacterial isolates of crustose coralline algae (Tebben et al. 2011), but is

239 commonly observed in high-density culture conditions (M. Miller, Pers Obs; J. Figueiredo, R.

240 Ritson-Williams, and C. Page, Pers. Comm.). Thus, the duration of availability of cultured

241 Acropora palmata larvae in our competency study likely yielded an underestimate of the

242 duration of the competence period for this species; i.e., it is likely substantially longer than 35

243 dAS.

244 Connectivity models consider several contributing processes to coral abundance,

245 including spawning output, dispersal, larval behavior, predation, habitat, and post-settlement

246 processes (Cowen and Sponaugle 2009). Our results highlight the intra- and inter-cohort

247 variability within spawning output, potential for dispersal, and larval behavior which may pose 
248 additional modelling challenges, and should be considered when estimating parameters for these

249 models. The dominant pattern in the competency assays is of high variability both between

250 years/cohorts and among replicates within individual trials. Some variation in settlement

251 response is likely due to variation in the quality or nature of the positive settlement cue present

252 on the field-conditioned substrate provided in each replicate of our experiment. It was only

253 possible to standardize these based on rough visual appearance, whereas microscopic biofilms

254 and subtle taxonomic distinctions of crustose coralline algae can profoundly affect settlement

255 induction (Harrington et al. 2004; Ritson-Williams et al. 2014; Tebben et al. 2015). There is also

256 evidence of a strong genetic component to settlement patterns, which can account for differences

257 between cohorts. For example, Kenkel et al. (2011) showed settlement response varying from

258 37-94\% (during a settlement period between 5-8 dAS) among full-sib families of Acropora

259 millepora. These different potential mechanisms of variability in overall settlement success may

260 yield somewhat different implications, not only for predicted connectivity but also in terms of

261 potential remedies. For example, a rehabilitation strategy for poor settlement habitat (i.e.

262 providing inadequate settlement cues) is different than a restoration strategy involved in selecting

263 parents for larval propagules that can be successful settlers. Indeed, both types of strategies may

264 be needed on modern, depauperate reefs.

Though the settlement response is highly variable, some characteristics are remarkably consistent between years, though contrasting between species (summarized in Table 3). For example, the initial observation of metamorphosis in the longevity studies (i.e., in absence of settlement cue) was either 10 or $11 \mathrm{dAS}$ for both Acropora species over three years and either day 4 or 7 for $O$. faveolata. Given these different ages of competency, the percent of larvae 
271 than for $O$. faveolata (55-58 \% on day 4-7) in the longevity study under the more benign (cool)

272 temperature treatments (Table 2, Fig 2). Knowledge of these consistent, species-specific

273 characteristics can be leveraged in developing and optimizing production pipelines for larval

274 propagules to meet the needs for large scale coral restoration (Baums et al. 2019; Randall et al.

275 2020).

Our temperature exposure treatments averaged about $1^{\circ} \mathrm{C}$ difference in 2015 and 2016.

277

278

279

280

281

282

283

284

285

286

287

288

289

290

291

292

293

This small temperature difference yielded subtle but significant differences in larval survivorship for both species. In 2017 , we implemented an average $1.5^{\circ} \mathrm{C}$ temperature increment between treatments (with maximum exposures in the high treatment reaching slightly over $32^{\circ} \mathrm{C}$ for a short period early in the experiment). This more extreme temperature regime caused more dramatic mortality, especially for Acropora spp. Nonetheless, even the less extreme 'warm' treatments, averaging $30.6-31^{\circ} \mathrm{C}(2015$ and 2016$)$ resulted in $24-39 \%$ fewer cumulative settlers over the entire course of larval duration (Table 2). Current mean monthly temperatures during the spawning season for these species, August through September, in the upper Florida Keys are already over $30^{\circ} \mathrm{C}$ (Kuffner et al. 2015; Manzello 2015), similar to our 'cool' treatment in 2016, but warmer than our cool treatment in 2015 and 2017.

Surprisingly, we did not observe more rapid onset of metamorphosis in the warm treatments of the longevity experiments (no cue) as several other studies have documented accelerated development timelines in warmer temperatures (Baums et al. 2013; Randall and Szmant 2009). In all cases but one, the first metamorphosis was observed on the same day in both temperature treatments. The exception was $O$. faveolata in 2015, in which case first metamorphosis was observed on day 7 in the warm and day 9 in the cool treatments. It may be that the previously documented acceleration of development rate in warmer temperatures results 
294 in differences in competency on the scale of hours (rather than days) and was thus not detectable

295 at the temporal resolution of our observations (1-2 days).

296 Conclusion:

These results provide a more solid basis for predicting dispersal of the key reef-building

298 Caribbean corals than has been previously available and, hence, the connectivity potential of

299 metapopulations of these foundation species. However, the realization of this potential is

300 predicated on successful larval production and successful recruitment into the receiving habitat

301 (i.e., settlement and survivorship to maturity). There is evidence that the latter process is failing

302 in many reefs (Hughes and Tanner 2000; van Woesik et al. 2014; Vermeij et al. 2011) and

303 growing suspicion that the former may also be impaired in areas where abundance and genotypic

304 diversity of adult populations is reaching depensatory levels (Hughes et al. 2019; NMFS 2015;

305 Williams et al. 2020). Models, even with improved parameter estimates provided by studies

306 such as this one, should not be interpreted as assuring connectivity. Restoration and other

307 management actions supporting successful coral sexual reproduction are also needed (Baums et

308 al. 2019; National Academies of Sciences 2019).

Acknowledgements: We thank C. Cameron, A. Peterson, L. Richter, B. Huntington, X. Serrano,

M. Connelly, C. Marmet, K. Kerr, E. Pontes, P. Colburn, C. Page, and L. MacLaughlin for assistance in field and lab. Acropora cervicornis larvae were graciously provided by The Florida

313 Aquarium and sourced from nursery brood stock of the Coral Restoration Foundation (Key 
315 Program and the Southeast Fisheries Science Center. Logistic support was also provided by the 316 Florida Keys National Marine Sanctuary. 
318

319

320

321

322

323

324

325

326

327

328

329

330

331

332

333

334

335

336

337

338

339

340

References Cited:

Baums IB, Baker AC, Davies SW, Grottoli AG, Kenkel CD, Kitchen SA, Kuffner IB, LaJeunesse TC, Matz MV, Miller MW. 2019. Considerations for maximizing the adaptive potential of restored coral populations in the western Atlantic. Ecological Applications 29:e01978.

Baums IB, Devlin-Durante MK, Polato NR, Xu D, Giri S, Altman NS, Ruiz D, Parkinson JE, Boulay JN. 2013. Genotypic variation influences reproductive success and thermal stress tolerance in the reef building coral, Acropora palmata. Coral Reefs 32:703-717.

Baums IB, Paris CB, Cherubin LM. 2006. A bio-oceanographic filter to larval dispersal in a reefbuilding coral. Limnology and Oceanography 51:1969-1981.

Connolly SR, Baird AH. 2010. Estimating dispersal potential for marine larvae: dynamic models applied to scleractinian corals. Ecology 91:3572-3583.

Cowen RK, Sponaugle S. 2009. Larval dispersal and marine population connectivity. Annual Reviews of Marine Science 1:443-466.

Davies SW, Strader ME, Kool JT, Kenkel CD, Matz MV. 2017. Modeled differences of coral life-history traits influence the refugium potential of a remote Caribbean reef. Coral Reefs 36:913-925.

Drury C, B. Paris C, Kourafalou V, Lirman D. 2018. Dispersal capacity and genetic relatedness in Acropora cervicornis on the Florida Reef Tract. Coral Reefs 37:585-596.

Gleason DF, Hofmann DK. 2011. Coral larvae: from gametes to recruits. Journal of Experimental Marine Biology and Ecology 408:42-57.

Graham EM, Baird AH, Connolly SR. 2008. Survival dynamics of scleractinian coral larvae and implications for dispersal. Coral Reefs 27(3):529-539. 
341 Harrington L, Fabricius K, De'ath G, Negri A. 2004. Recognition and selection of settlement substrata determine post-settlement survival in corals. Ecology 85:3428-3437.

343

Holstein DM, Paris CB, Mumby PJ. 2014. Consistency and inconsistency in multispecies population network dynamics of coral reef ecosystems. Marine Ecology Progress Series 499:1-18.

Hughes TP, Kerry JT, Baird AH, Connolly SR, Chase TJ, Dietzel A, Hill T, Hoey AS, Hoogenboom MO, Jacobson M, Kerswell A, Madin JS, Mieog A, Paley, AS, Pratchett MS, Torda G, Woods RM. 2019. Global warming impairs stock-recruitment dynamics of corals. Nature 568:387-390.

Hughes TP, Tanner JE. 2000. Recruitment failure, life histories, and long-term decline of Caribbean corals. Ecology 81:2250-2263.

Indrayanti E, Zainuri M, Sabadono A, Wijayanti DP, Pranowo WS, Siagian HSR. 2019. Larval dispersal model of coral Acropora in the Karimunjawa Waters, Indonesia. Biodiversitas Journal of Biological Diversity 20(7).

Kassambara A, Kosinski M, Przemyslaw B, Scheipl F. survminer: Drawing Survival Curves using 'ggplot2'. R package version 0.4.6., https:/CRAN.Rproject.org/package $=$ survminer .

Kenkel CD, Traylor MR, Wiedenmann J, Salih A, Matz MV. 2011. Fluorescence of coral larvae predicts their settlement response to crustose coralline algae and reflects stress. Proceedings of the Royal Society Biological Sciences Series B 278:2691-2697.

Kool JT, Paris CB, Barber PH, Cowen RK. 2011. Connectivity and the development of population genetic structure in Indo-West Pacific coral reef communities. Global Ecology and Biogeography 20(5):695-706. 
364 Kuffner IB, Lidz BH, Hudson JH, Anderson JS. 2015. A century of ocean warming on Florida

365 Keys coral reefs: historic in situ observations. Estuaries and Coasts 38:1085-1096.

366 Manzello DP. 2015. Rapid recent warming of coral reefs in the Florida Keys. Scientific Reports

$367 \quad 5: 16762$.

368 Miller K, Mundy C. 2003. Rapid settlement in broadcast spawning corals: implications for larval 369 dispersal. Coral Reefs 22:99-106.

370 Moneghetti J, Figueiredo J, Baird AH, Connolly SR. 2019. High-frequency sampling and 371 piecewise models reshape dispersal kernels of a common reef coral. Ecology 100:e02730. 372 National Academies of Sciences Engineering and Medicine. 2019. A Decision Framework for Interventions to Increase the Persistence and Resilience of Coral Reefs. Washington, DC: The National Academies Press.

375

376

377

378

379

380

381

382

NMFS. 2015. Recovery Plan for Elkhorn (Acropora palmata) and Staghorn (A. cervciornis) Corals. Prepared by the Acropora Recovery Team for the National Marine Fisheries Service. Silver Spring, Maryland.

Nozawa Y, Harrison P. 2008. Temporal patterns of larval settlement and survivorship of two broadcast-spawning acroporid corals. Marine Biology 155:347-351.

Randall C, Szmant A. 2009. Elevated temperature affects development, survivorship, and settlement of the elkhorn coral, Acropora palmata (Lamarck 1816). Biological Bulletin 217:269-282.

Randall CJ, Negri AP, Quigley KM, Foster T, Ricardo GF, Webster NS, Bay LK, Harrison PL, Babcock RC, Heyward AJ. 2020. Sexual production of corals for reef restoration in the Anthropocene. Marine Ecology Progress Series 635:203-232. 
386

387

388

389

390

391

392

393

394

395

396

397

398

399

400

401

402

403

404

405

406

407

Ritson-Williams R, Arnold SN, Paul VJ, Steneck RS. 2014. Larval settlement preferences of Acropora palmata and Montastraea faveolata in response to diverse red algae. Coral Reefs 33:59-66.

Schill SR, Raber GT, Roberts JJ, Treml EA, Brenner J, Halpin PN. 2015. No reef is an island: integrating coral reef connectivity data into the design of regional-scale marine protected area networks. PLoS One 10(12): e0144199.

Tay YC, Guest JR, Chou LM, Todd PA. 2011. Vertical distribution and settlement competencies in broadcast spawning coral larvae: Implications for dispersal models. Journal of Experimental Marine Biology and Ecology 409:324-330.

Tebben J, Motti CA, Siboni N, Tapiolas DM, Negri AP, Schupp PJ, Kitamura M, Hatta M, Steinberg PD, Harder T. 2015. Chemical mediation of coral larval settlement by crustose coralline algae. Scientific Reports 5:10803.

Tebben J, Tapiolas DM, Motti CA, Abrego D, Negri AP, Blackall LL, Steinberg PD, Harder T. 2011. Induction of larval metamorphosis of the coral Acropora millepora by Tetrabromopyrrole isolated from a Pseudoalteromonas bacterium. PLoS ONE 6(4):e19082.

Therneau TM. 2020. A Package for Survival Analysis in R, R package version 3.2-3, https://CRAN.R-project.org/package=survival

van Woesik R, Scott WJ, Aronson RB. 2014. Lost opportunities: Coral recruitment does not translate to reef recovery in the Florida Keys. Marine Pollution Bulletin 88:110-117.

Vermeij MJ, Bakker J, Hal Nvd, Bak RP. 2011. Juvenile coral abundance has decreased by more than $50 \%$ in only three decades on a small Caribbean island. Diversity 3:296-307. 
408 Williams D, Nedimyer K, Miller M. 2020. Genotypic inventory of Acropora palmata

409 (elkhorn coral) populations in south Florida. Miami FL, NOAA National Marine

410 Fisheries Service Southeast Fisheries Science Center Protected Resources and

411 Biodiversity Division Report NOAA/SEFSC/PRBD-2020-1.

412

413 


\section{Table $\mathbf{1}$ (on next page)}

Experimental parameters

Collections were attempted each year, but there were not always adequate larvae of each species to run one or both experiments. Competency assays (COMP) were begun in 2012, while Longevity assays (LONG) were begun in 2015. Two separate cohorts of O.faveolata (a and b; born on successive nights) were tested separately in 2013. Ofav = Orbicella faveolata, Aplam $=$ Acropora palmata, Acerv=Acropora cervicornis. Horseshoe $25.140^{\circ} \mathrm{N} 80.294^{\circ} \mathrm{W}$; Elbow $25.143^{\circ} \mathrm{N} 80.258^{\circ} \mathrm{W}$; Grecian Rocks $25.110^{\circ} \mathrm{N} 80.306^{\circ} \mathrm{W}$; Sand Island $25.018^{\circ} \mathrm{N}$ $80.368^{\circ} \mathrm{W}$; Molasses 25.010oN 80.375oW; 


\begin{tabular}{|c|c|c|c|c|c|c|c|}
\hline Year & Species & $\begin{array}{l}\text { Spawn } \\
\text { location }\end{array}$ & $\begin{array}{l}\text { Number } \\
\text { of } \\
\text { parents }\end{array}$ & $\begin{array}{l}\text { Spawn } \\
\text { date }\end{array}$ & Expt dates & $\begin{array}{l}\text { Mean }( \pm 1 S D) \\
\text { culture } \\
\text { temperature }\end{array}$ & NOTES \\
\hline 2012 & Ofav & Horseshoe & unk & 8 Aug & 21 Aug-25 Sept & $29.1 \pm 1.00$ & $\begin{array}{l}\text {-Competency assays not } \\
\text { begun until } 14 \mathrm{~d} \text { AS }\end{array}$ \\
\hline \multirow[t]{3}{*}{2013} & Apalm & Elbow & 6 & 24 Aug & 28 Aug-6 Sept & \multirow[t]{3}{*}{$29.2 \pm 0.65$} & \\
\hline & $\begin{array}{l}\text { Ofav: } \\
\text { Cohort a }\end{array}$ & Sand Island & 2 & 26 Aug & 28 Aug-25 Oct & & \\
\hline & $\begin{array}{l}\text { Ofav: } \\
\text { Cohort b }\end{array}$ & $\begin{array}{l}\text { Grecian } \\
\text { Rocks }\end{array}$ & $<8$ & 27 Aug & 6 Sept-4 Oct & & \\
\hline \multirow[t]{2}{*}{2014} & Apalm & $\begin{array}{l}\text { Molasses } \\
\text { and Elbow }\end{array}$ & 7 & 15 Aug & 18 Aug-1 Sept & \multirow[t]{2}{*}{$28.5 \pm .051$} & \multirow{2}{*}{$\begin{array}{l}\text {-Ceramic plug chips } \\
\text { conditioned } \sim 2 \text { mos } \\
\text { substituted for natural } \\
\text { rubble chip in } \\
\text { competence assays }\end{array}$} \\
\hline & Ofav & $\begin{array}{l}\text { Horseshoe } \\
\text { and } \\
\text { Grecian } \\
\text { Rocks }\end{array}$ & unk & 17 Aug & 20 Aug-14 Sept & & \\
\hline \multirow[t]{2}{*}{2015} & Apalm & $\begin{array}{l}\text { Elbow and } \\
\text { Sand Is. }\end{array}$ & 5 & 4 Aug & $\begin{array}{l}\text { LONG: } 6 \text { Aug- } 6 \\
\text { Oct }\end{array}$ & \multirow[t]{2}{*}{$29.5 \pm 0.59$} & \multirow{2}{*}{$\begin{array}{l}\text {-Glass inserts begun for } \\
\text { competency assays } \\
\text {-Insufficient Apalm to } \\
\text { run competency assays }\end{array}$} \\
\hline & Ofav & Horseshoe & $>8$ & 6 Aug & $\begin{array}{l}\text { LONG: } 7 \text { Aug-27 } \\
\text { Oct } \\
\text { COMP: 9-25 Aug }\end{array}$ & & \\
\hline 2016 & Apalm & Elbow & 5 & 21 Aug & $\begin{array}{l}\text { LONG: } 22 \text { Aug-31 } \\
\text { Oct } \\
\text { COMP: } 25 \text { Aug-4 } \\
\text { Sept }\end{array}$ & $29.9 \pm 0.15$ & $\begin{array}{l}\text {-Settlement assay done } \\
25-26 \text { Sept with } \\
\text { remaining 'warm' dish } \\
\text { larvae } \\
\text {-No Ofav larvae available }\end{array}$ \\
\hline \multirow[t]{3}{*}{2017} & Apalm & $\begin{array}{l}\text { Elbow and } \\
\text { Horseshoe }\end{array}$ & 4 & 10 Aug & $\begin{array}{l}\text { LONG: } 11 \text { Aug-6 } \\
\text { Sept }\end{array}$ & $29.5 \pm 0.64$ & $\begin{array}{l}\text {-Larvae from LONG } \\
\text { pooled for final }\end{array}$ \\
\hline & Acerv & $\begin{array}{l}\text { CRF coral } \\
\text { nursery }\end{array}$ & unk & 10 Aug & $\begin{array}{l}\text { LONG: } 11 \text { Aug-6 } \\
\text { Sept } \\
\text { COMP: } 14-25 \\
\text { Aug }\end{array}$ & \multirow[t]{2}{*}{$30.9 \pm 0.84$} & \multirow{2}{*}{$\begin{array}{l}\text { settlement assays } 6 \text { Sept } \\
\text { prior to Hurricane } \\
\text { evacuation } \\
\text {-Insufficient Apalm to } \\
\text { run competency assays }\end{array}$} \\
\hline & Ofav & Horseshoe & $>8$ & 13 Aug & $\begin{array}{l}\text { LONG, COMP: } 15 \\
\text { Aug-6 Sept }\end{array}$ & & \\
\hline
\end{tabular}




\section{Table 2 (on next page)}

Observed cumulative settlement in the larval longevity experiments (i.e., no settlement cue added)

'Warm' and 'Cool' treatments varied somewhat in both mean and variability between experiments in different years (see Table 1 ) but ranged between 29 and $32^{\circ} \mathrm{C} . \mathrm{dAS}=$ days after spawn 
1

2

\begin{tabular}{lcccccccc} 
Year & Species & $\begin{array}{c}\text { Experiment } \\
\text { duration } \\
\text { (days) }\end{array}$ & $\begin{array}{c}\text { cumulative } \% \\
\text { Settlement }\end{array}$ & $\begin{array}{c}\text { Proportion } \\
\text { fewer } \\
\text { settlers in } \\
\text { warm }\end{array}$ & $\begin{array}{c}\text { Mean } \\
\text { observed } \\
\text { metamor- } \\
\text { marm }\end{array}$ & $\begin{array}{c}\text { cool } \\
\text { phosis (dAS) }\end{array}$ & $\begin{array}{c}\text { Mean \% larvae } \\
\text { remaining at first } \\
\text { observed } \\
\text { metamorphosis }\end{array}$ \\
\hline 2015 & O. faveolata & 83 & 8 & 13 & 0.39 & 7 & warm & cool \\
2015 & A. palmata & 63 & 29 & 38 & 0.24 & 11 & 70 & 54 \\
2016 & A. palmata & 70 & NA & 21 & NA & 10 & 70 & 71 \\
2017 & A. palmata & $25^{*}$ & 9 & 27 & 0.67 & 11 & 59 & 83 \\
2017 & A. cervicornis & $25^{*}$ & 8 & 23 & 0.64 & 11 & 28 & 71 \\
2017 & O. faveolata & $23^{*}$ & 2 & 2 & 0 & 4 & 55 & 58
\end{tabular}

*2017 experiments aborted at day 23-25 due to Hurricane Irma evacuation 


\section{Table 3 (on next page)}

Summary of species-specific differences in observed larval characteristics

Values given in the first three rows are drawn from one or two corhorts of Orbicella faveolata and three cohorts of Acropora palmata (Fig 2). The last two rows are drawn from six cohorts of O.faveolata and three cohorts of A.palmata (Fig. 3, 4). Only one cohort of A.cervicornis was addressed in this study. dAS = days After Spawn 
1

2

Maximum longevity (days)

First observed metamorphosis (dAS; without cue)

$\%$ larvae alive at first metamorphosis (cool treatment)

Onset of competency (with cue)

Maximum mean settlement $24^{-\mathrm{h}}$ (with cue)

\begin{tabular}{ccc}
$\begin{array}{c}\text { Orbicella } \\
\text { faveolata }\end{array}$ & $\begin{array}{c}\text { Acropora } \\
\text { palmata }\end{array}$ & $\begin{array}{c}\text { Acropora } \\
\text { cervicornis* }\end{array}$ \\
\hline 83 & 70 & N/A \\
$4-7$ & $10-11$ & 11 \\
$54-58 \%$ & $71-83 \%$ & $71 \%$ \\
day 3-5 & day 6-8 & day 8 \\
$55 \%$ & $83 \%$ & $67 \%$
\end{tabular}

*data from only a single cohort of $A$. cervicornis and for which longevity study was truncated at day 25 


\section{Figure 1}

Illustration of one replicate of the competency assay

(A) Small chip of reef rubble providing benthic settlement cues and O.faveolata larvae (small white dots) in one well of a 6-well culture dish. (B) Appearance of O.faveolata larvae scored as successful settlement with attached, flattened appearance, and substantial progress of metamorphosis. 


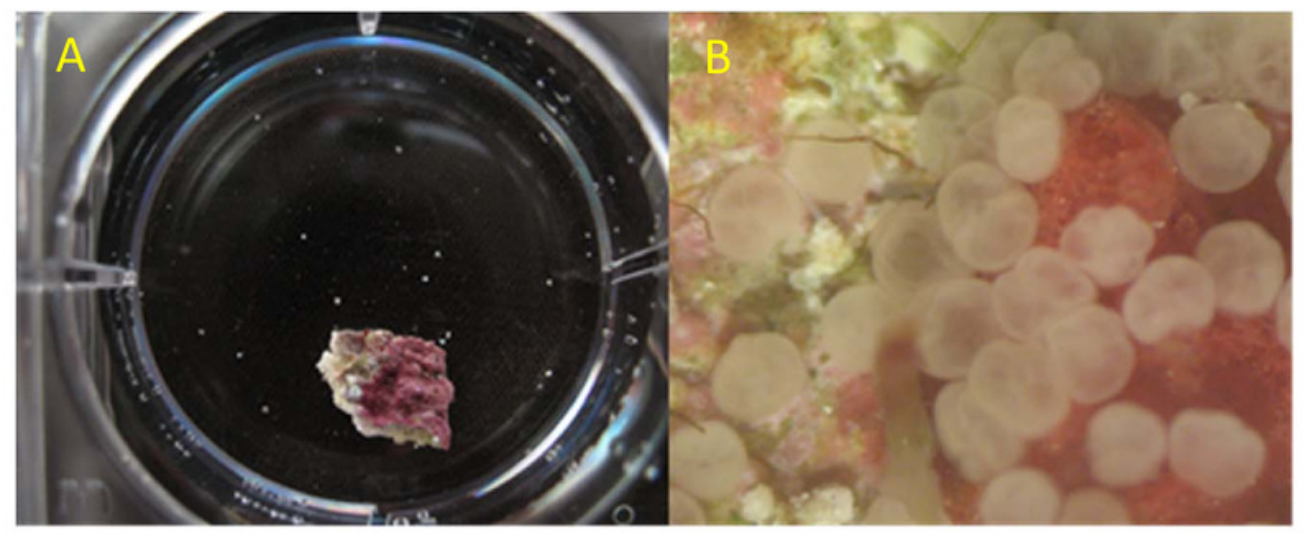




\section{Figure 2}

Larval persistence under different temperatures

Kaplan-Meier curves for swimming pelagic larvae in two temperature treatments (described in Table 1) for Acropora spp. (A-D) and Orbicella faveolata (E-F) cohorts. This shows the probability of remaining as swimming pelagic larvae over time; reduced by both mortality and metamorphosis (in the absence of specific settlement cues). Dashed line shows the time when first metamorphosis was observed in each trial. P-values show significance of difference between the two curves via log rank test. Legends also show the mean observed settlement in the $n=5$ dishes of each treatment. 

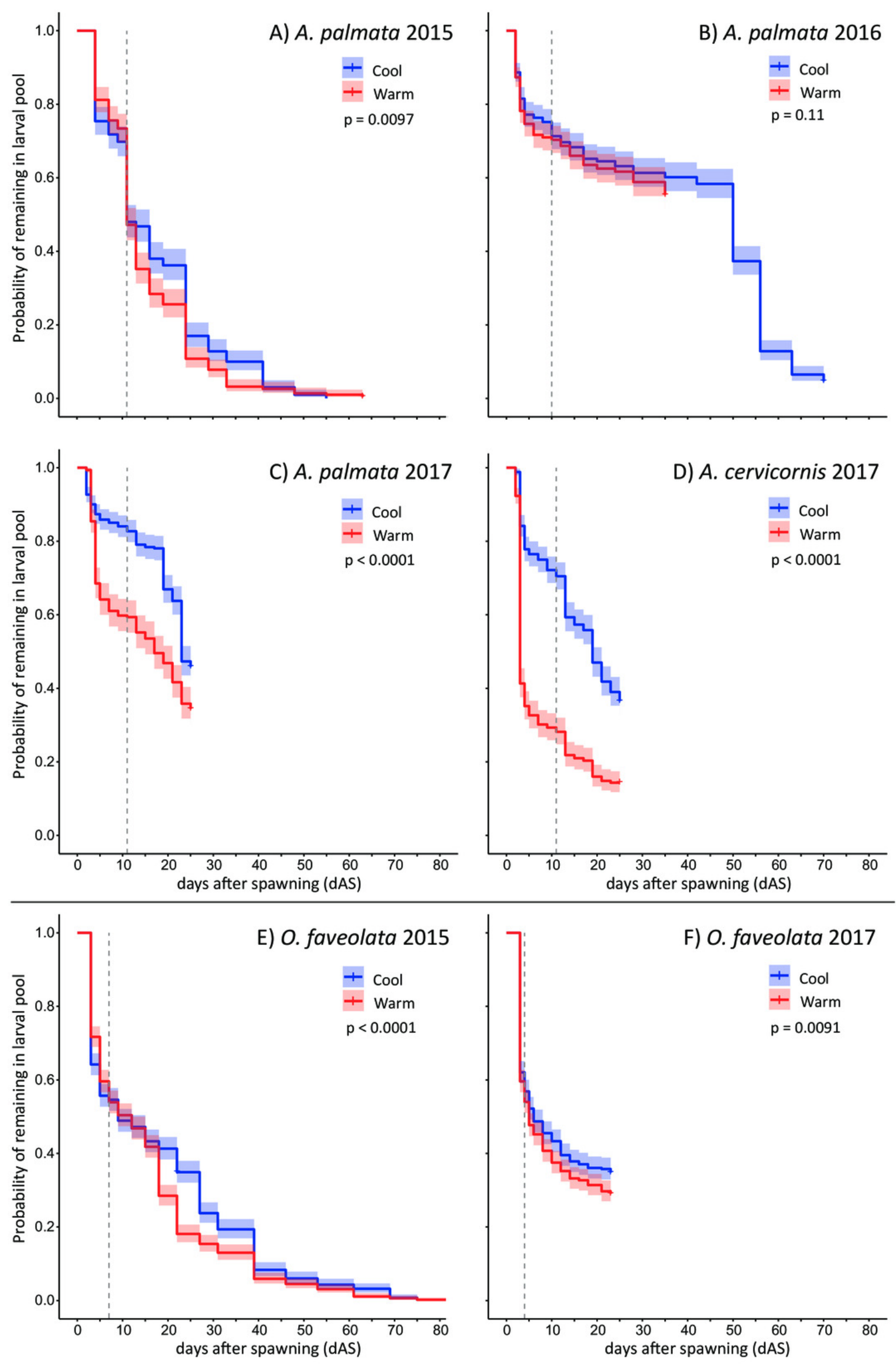

Peer) reviewing PDF | (2020:04:48375:1:1:NEW 10 Jul 2020) 


\section{Figure 3}

Competency assays - Acropora spp.

Settlement in sequential, 24-h assays with four different cohorts of larvae of Acropora spp. A)-C) are A. palmata while D) is A. cervicornis. A separate aliquot of larvae was used for each trial. Triangles show raw data for $n=12$ replicates on each occasion. Red dash shows the mean. 


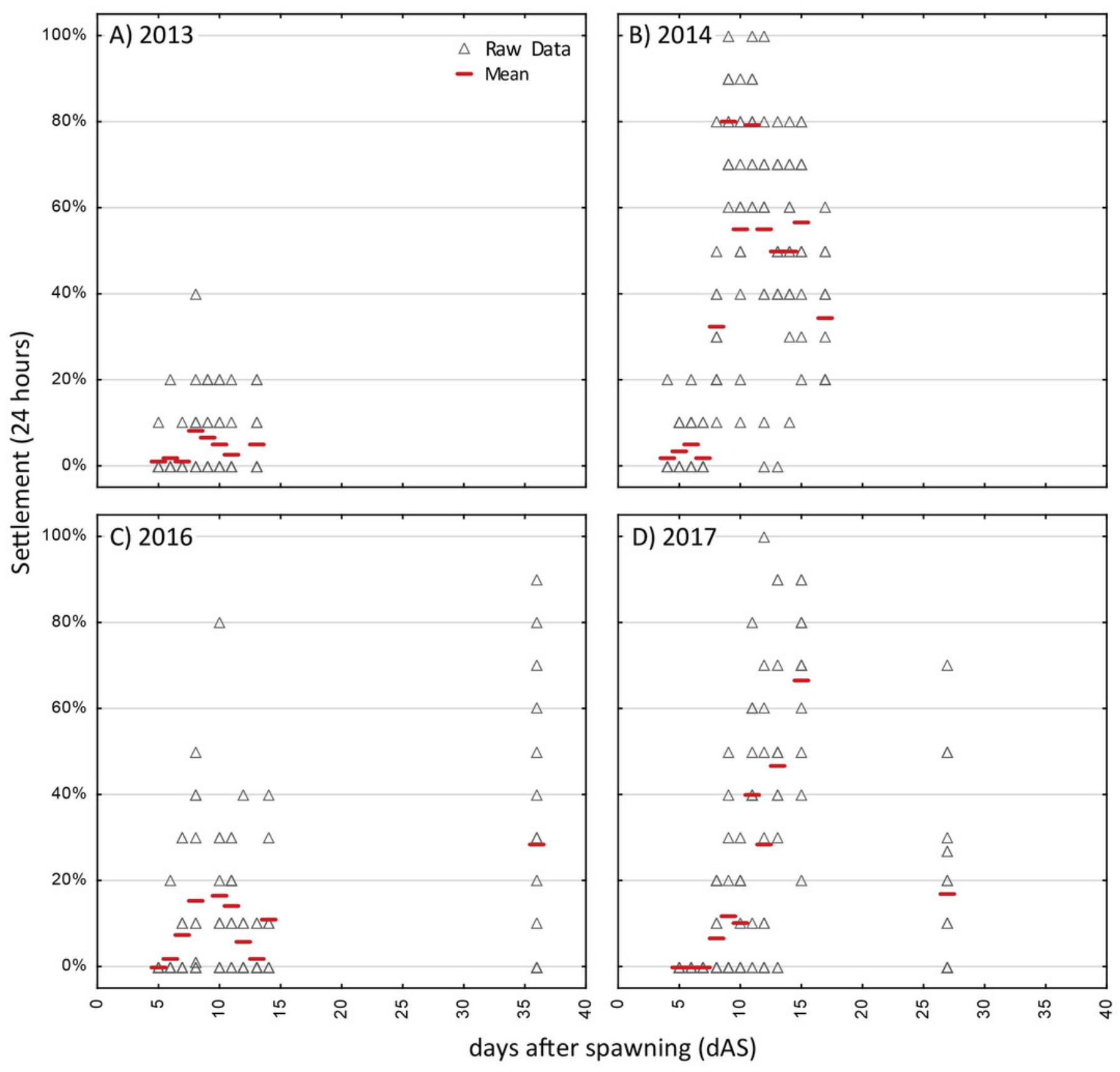


Figure 4

Competency assays - Orbicella faveolata

Settlement in sequential, 24-h assays with six different cohorts of larvae of Orbicella faveloata over five years (A-F). A separate aliquot of larvae was used for each trial. Triangles show raw data for $n=12$ replicates on each occasion. Red dash shows the mean.
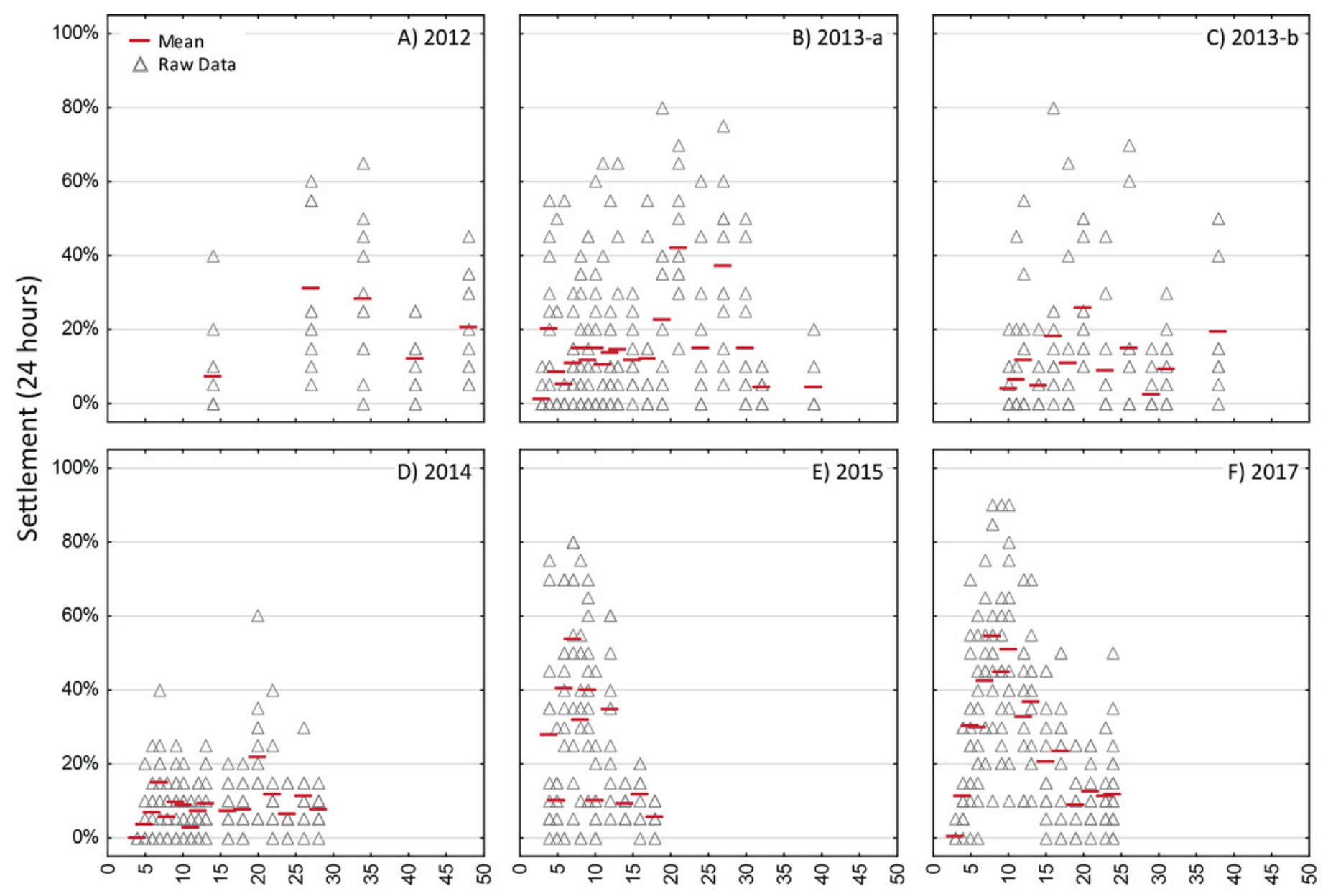

days after spawning (dAS) 